\title{
KNOWLEDGE OF SAMAGRA PROJECT BENEFICIARIES ON SCIENTIFIC GOAT MANAGEMENT PRACTICES
}

\section{DR. ANU GEORGE ${ }^{1}$ \& DR. JIJI R. S}

${ }^{1}$ Assistant Professor, Department of Veterinary and Animal Husbandry Extension, College of Veterinary and Animal Sciences, Mannuthy, Thrissur, Kerala, India

${ }^{2}$ Professor and Head, Department of Veterinary and Animal Husbandry Extension, College of Veterinary and Animal Sciences, Mannuthy, Thrissur, Kerala, India

KEYWORDS: Kudumbashree, Self-help groups, Scientific management, Training Need Assessment, Focus Group Discussion, Goat Village Scheme

Received: Sep 07, 2020; Accepted: Sep 27, 2020; Published: Dec 04, 2020; Paper Id.: IJHRMROCT20201

\section{INTRODUCTION}

Goat is known as poor man's cow. Being easily digestible, goat milk is a good supplement for children and convalescent people. In addition to that they are among the main meat-producing animals in India,and goat meat (chevon) is one of the choicest meats and has huge domestic demand. Due to its good economic prospects, goat rearing under intensive and semi-intensive system for commercial production has been gaining momentum for the past couple of years. High demand for goat and its products with potential of good economic returns have been deriving many progressive farmers, businessmen, professionals, ex-servicemen and educated youths to take up the goat enterprise on a commercial scale. The emerging favourable market conditions and easy accessibility to improved goat technologies are also catching the attention of entrepreneurs. A number of commercial goat farms have been established in different regions of the country.

Goat farming is an important subsector of animal husbandry in Kerala. It plays a crucial role in the welfare of the rural population by providing livelihood support. There is possibility of finding full time employment throughout the year through goat farming. Goat farming is an important source of subsidiary income to many small and marginal farmers and also agricultural labourers. 
Samagra Project is an initiative independently developed by Kudumbashree and being implemented in the State in collaboration with the three tier local governments and other agencies. It is an attempt to address the entire production supply value chain holistically, by scaling up productive activity both qualitatively and quantitatively and seeking viable supply opportunities. The major Samagra projects that are implemented in livestock sector are Ksheera sagaram (Dairy project) and Aadugramam (Goat Village Scheme).

Goat village project has been an attempt to approach homestead based goat rearing as an enterprise through an integrated approach combining traditional knowledge and scientific rearing practices. It is a Samagra project and therefore adopted an integrated approach covering backward and forward linkages, keeping homestead level goat rearing unit at its centre. It also attempted collaboration of various agencies and institutions characteristic of Samagra projects. Samagra projects have been developed considering local situation in each region, leveraging on the strengths of traditional agriculture, industry, and markets. The portfolio of projects has been quite diverse. Samagra approach has been part of a new strategy in enterprises promotion. Samagra is about an integrated approach to enterprises. It used the knowledge of people who have been rearing goats traditionally.

Regional Research and Training Centre of Kerala Veterinary and Animal Sciences University conducts need based trainings for the animal husbandry stake holders of southern region of Kerala. Knowledge level is assessedand Training Need Assessment (TNA) was conducted employing the participatory methods like stakeholder workshops and Focus Group Discussions. Livestock sector based stakeholders like dairy and poultry farmers, entrepreneurs, veterinary officers, Kudumbashree district and block coordinators, self-help group members and Community Development Society (CDS) chairpersons were involved in the discussions. Based on the results, beneficiaries of Aadugramam scheme were given trainings on commercial goat rearing.

The goat farmers are pointing out some difficulties in rearing the animals. Some of them being non-profitability of the enterprise, unprecedented increase in feed cost, scarcity of labourers, unavailability of fodder and water and occurrence of diseases that make the animal unproductive. Increasing the profit by minimising cost of production and maximising the returns is a major challenge faced by the goat farmers. To some extent these problems could be addressed by adoption of scientific management practices.

Management of animals can be considered under the topics like selection of animals, housing, feeding, breeding and general care of animals. In goat rearing units, usually there would not be covered sheds and the animals are kept in the open. It cannot offer protection against snake bites or provide shelter against extreme environmental conditions. Earlier, the local non-descript breeds were resistant to most of the diseases and there was no financial loss to the farmer due to it. In the modern age, where the multivariant strains of micro-organisms cause new and emergent diseases to the cross-bred animals, the goat farmers should be more vigilant. According to Vidya et al. (2010), knowledge has an important role in bringing behavioural changes to an individual, in better decision making and forming a favourable attitude which will result in adoption of scientific management practices.

Now there are many Self Help Groups taking goat farming as the income generating activity. But being unaware of the scientific management practices, many of the units had to end up the enterprise in the forming stage itself. Hence at this context the study was undertaken in Thiruvananthapuram district with the following objectives

- To study the socio-psychological profile of goat farmers 
- To study the knowledge of goat farmers on scientific management practices

- The constraints felt by the farmers in goat rearing

\section{METHODOLOGY}

Livestock farmers of Thiruvananthapuram district included in the Samagra Animal Husbandry project of Kudumbashree were the respondents of the study. The two animal husbandry projects implemented in Thiruvananthapuram district under Samagra were Ksheera Sagaram (Dairy Cattle scheme) and Aadugramam (Goat Village scheme). As a continuing capacity building programme, Kerala Veterinary and Animal Sciences University had been involved in the scheme and conducted the study.

During 2013-14 there were twenty CDS involved in these projects which served as the population. The following seven CDS were selected randomly from the district.

- Pothencode

- Malayinkeezhu

- Karakulam

- Venganoor

- Aryanad

- Athiyannoor

Livestock farmer members of those CDS were invited for the focus group discussions and personal interviews which were organised at the respective locality to suggest the training needs regarding the commercial goat farming practices.Knowledge in scientific goat management practices and Constraints in goat rearing weremeasured by the Scheduledeveloped by Jacob and George (2013). The data obtained were analysed using simple statistical tools like frequency and percentage.

\section{RESULTS}

Table 1: Personal profile of goat farmers $\quad n=100$

\begin{tabular}{|c|c|c|c|c|}
\hline Sl. No & & Category & Frequency & $\%$ \\
\hline \multirow[t]{3}{*}{1} & \multirow[t]{3}{*}{ Age } & $<35$ years & 02 & 02 \\
\hline & & $35-50$ yrs. & 88 & 88 \\
\hline & & $>50$ yrs. & 10 & 10 \\
\hline \multirow[t]{3}{*}{2} & \multirow[t]{3}{*}{ Educational Status } & $<5$ years & 15 & 15 \\
\hline & & 5-8 years & 77 & 77 \\
\hline & & $>8$ years & 08 & 08 \\
\hline \multirow[t]{4}{*}{3} & \multirow[t]{4}{*}{ Major Occupation } & Agriculture & 10 & 10 \\
\hline & & Livestock rearing & 42 & 42 \\
\hline & & Business & 3 & 3 \\
\hline & & $\begin{array}{l}\text { Coolie (Agricultural/ non-agri. } \\
\text { labour) }\end{array}$ & 45 & 45 \\
\hline 4 & Annual Income & $<25000$ & 67 & 67 \\
\hline
\end{tabular}




\begin{tabular}{|c|c|c|c|c|}
\hline & & $>25000$ & 33 & 33 \\
\hline \multirow[t]{3}{*}{5} & \multirow[t]{3}{*}{ Number of goat owned } & $<4$ & 34 & 34 \\
\hline & & $4-8$ & 40 & 40 \\
\hline & & $>8$ & 26 & 26 \\
\hline \multirow[t]{2}{*}{6} & \multirow[t]{2}{*}{ Land Owned } & $<10$ cents & 88 & 88 \\
\hline & & $>10$ cents & 12 & 12 \\
\hline \multirow[t]{3}{*}{7} & \multirow[t]{3}{*}{ Family Size } & $<4$ members & 73 & 72 \\
\hline & & 4-7 members & 23 & 23 \\
\hline & & $>7$ members & 4 & 4 \\
\hline \multirow[t]{3}{*}{8} & \multirow{3}{*}{$\begin{array}{l}\text { Experience in goat } \\
\text { Farming }\end{array}$} & $<5$ years & 68 & 68 \\
\hline & & $5-10$ years & 30 & 30 \\
\hline & & $>10$ years & 2 & 2 \\
\hline \multirow[t]{2}{*}{9} & \multirow[t]{2}{*}{ Experience in SHGs } & $<5$ years & 44 & 44 \\
\hline & & $>5$ years & 46 & 46 \\
\hline
\end{tabular}

The profile data revealed that majority of the Samagra members were middle aged omen having 5-8 years of formal education, low income and marginal farmers. Major occupation was livestock rearing or agriculture labour. They reared 4-8 goats on an average and had only less than five years of experience in rearing goats. Had small family and had above five years of experience in SHGs. According to George (2005) majority of the livestock farmers of Kerala were lowincome marginal farmers having primary education.

\section{Knowledge on Scientific Management Practises}

Table 2: Distribution of goat farmers on knowledge of scientific management $\quad n=100$

\begin{tabular}{|l|l|l|l|}
\hline \multicolumn{1}{|c|}{ Category } & \multicolumn{1}{c|}{ Percentage score } & \multicolumn{1}{c|}{ Frequency } & percentage \\
\hline Excellent & $>86$ & 15 & 15 \\
\hline Good & $71-85$ & 28 & 28 \\
\hline Fair & $51-70$ & 17 & 17 \\
\hline Poor & $<50$ & 40 & 40 \\
\hline Total & 100 & 100 \\
\hline
\end{tabular}

The data revealed that 15 per cent of the goat farmers were having excellent level of knowledge, 28 per cent had good, 17 per cent had fair and 40 per cent had only poor level of knowledge on scientific management practices.The findings of the study was supported by the findings of Shanmugam et al., (2002) who reported that the dairy farmers had only fair knowledge on the vital information regarding dairy cattle breeding. According to Kavitha (2005), 16 per cent of the goat keepers had high, 75.33 per cent had medium and 8.67 per cent had low knowledge on goat management.As per Vidya et al. (2010), about three-fourth of the dairy farmers had only medium level of knowledge on dairy health management practices. Lahoti et.al. (2011) also described knowledge as one of the important components of adoption behaviour. They also reported that age, attitude towards indigenous technology, use of sources of information and level of scientific orientation were having influence on knowledge level. Tak et al., (2011) showed that extension contact, mass media exposure, education and herd size were having significant positive correlation with knowledge. George and Subhadra (2002) reported that 38 per cent of the beneficiaries of calf feed subsidy scheme were highly knowledgeable, 35 per cent had medium and 27 per cent had only low level of knowledge on preventive vaccination.

\section{Constraints in Goat Rearing}

Constraints are the problems or difficulties faced by the goat farmer in carrying out the activities of goat farming. The constraints indicated by the farmers are presented in Table 3. 
Table 3: Distribution of the goat farmers based on the constraints felt $\quad n=100$

\begin{tabular}{|c|l|c|c|c|}
\hline SI. No & \multicolumn{1}{|c|}{ Constraint } & Frequency & Percentage & Rank \\
\hline 1 & High cost of feed & 100 & 100 & I \\
\hline 2 & Non-availability of enough fodder & 80 & 80 & II \\
\hline 3 & Problem of repeat breeding & 70 & 70 & III \\
\hline 4 & Scarcity of water & 68 & 68 & IV \\
\hline 5 & Less availability of grazing land & 63 & 63 & V \\
\hline 6 & High cost of medicines & 57 & 57 & VI \\
\hline 7 & High cost of animals & 55 & 55 & VII \\
\hline 8 & Infectious diseases especially mastitis & 53 & 53 & VIII \\
\hline 9 & Increased labour cost & 48 & 48 & IX \\
\hline 10 & Difficulty in getting bank loans sanctioned & 35 & 35 & X \\
\hline
\end{tabular}

Constraints are the factors that act as a bottleneck and restrict the system from achieving its objectives (Jacob and George, 2011). High cost of feed is the most important constraints felt by almost all the respondents and accordingly was ranked I. Among the others non-availability of enough fodder, problem of repeat breeding, scarcity of water, less availability of grazing land, high cost of medicines, high cost of animals, occurrence of infectious diseases especially mastitis were the important constraints pointed out by more than half of the goat farmers. Related results are shown by Rani (2004). The problem of increased labour cost and non-availability of labourers was indicated by $48 \%$ of the respondents. Another constraint coming next in the rank order is the difficulty of getting bank loans sanctioned (35\%).It is a new and emerging situation. Even if the Government is implementing projects to support the rural poor, they are not receiving them due to their unpaid previous loans. According to Rathod (2011) non-availability of enough dry fodder, problem of repeat breeding, scarcity of water, less availability of grazing land and high cost of medicines were the important constraints in livestock rearing. Shinde (2011) suggested that high cost of milch animals, non-adaptation of animals bought from faraway places and occurrence of infectious diseases especially mastitis were the important constraints pointed out by majority of the dairy farmers.

\section{CONCLUSIONS}

There is a gap, though not wide, existing in the dissemination of animal husbandry related knowledge to the rural farmers. Most of the research findings are not getting transferred to the actual target group, i.e. the farmers. Mostof the information was transferred without being well documented in books or other extension services. Lack of proper knowledge leads to many unscientific practices being followed in the goat rearing sector leading to diseases and consequent losses to goat farmers. As a result, they will be forced to stop the enterprise. This probably causes serious impact in the population figures and hence the milk and meat production. Hence it's high time to bridge this knowledge gap through proper awareness campaigns and trainings.

For better managing the animals, the owners should be made access to right information and expertise at the right time in the needy areas. The skill required will differ between owners according to the prevailing situation. Even with an array of development initiatives in agricultural extension in India in the past decades, the quality of information provided to farmers is uneven (Glendenning et al 2010). Identifying the knowledge level and information needs of the owners will enable the extension system to serve them better with right information and skill.

Babu et al (2012) criticised that public agricultural extension systems often failed due to inadequate consultation of farmers about their information needs and poor understanding of their information search strategies. Hence, suitable training programmes are to be implemented, giving due concern to the training needs of the dairy farmers on scientific 
management of cattle. Factors such as literacy or access to sources will have a large impact on information needs and use of information sources (Glendenning et al 2010).

\section{REFERENCES}

1. Babu S. C. Glendenning C. J. Okyere A. K. Govindarajan, S. K. 2012. Farmers' information needs and search behaviours-case study in Tamil Nadu, India, IFPRI discussion Paper 1165, Washington D. C, 48p

2. George, A.2005. Awareness and participation of livestock farmers in Panchayati Raj System. Unpublished M.V.Sc. thesis submitted to $K A U, 154 \mathrm{p}$

3. George, R.P. and Subhadra, M.R. (2002) 'Impact of calf feed subsidy scheme on knowledge of farm women about disease control' Indian Vet.J.79:697-699

4. Srinivasa Rao, A. B., P. M. Kumar, and P. S. Aithal. "Strategic Planning in Higher Education Institutions: A Case Study of SIMS-VISION 2025." International Journal of Educational Science and Research (IJESR) ISSN (P) (2015): 2249-6947.

5. Glendenning, C.J. Babu, S. C. Asenso, O. K. 2010. Review of agricultural extension in India-Are farmers' information needs being met? IFPRI Discussion paper 1048, International Food Policy Research Institute, Washington D.C.35 p

6. Saikia, Karuna Kanta, and Chandrama Goswami. "Nature and Extent of Income Diversification: A Study of Rural Households in Assam." International Journal of Economics, Commerce and Research (IJECR) 5.5 (2015): 43-54.

7. Jacob, S.K. and George, A. (2011) 'Socio-economic profile and constraints of dairy farmers in Kerala'. J. Ext Edn. 23(3): $4699-4702$

8. Jacob,S.K. and George, A. (2013) Capacity building of goat farmers in Kerala-Assessment of knowledge, attitude and training needs, Lap Lambert Academic Publishers, 108 p

9. Kavitha, V. (2005) 'Perception of empowerment by the members of women self help group in goat farming in Trichur district' M.V.Sc thesis, Kerala Agricultural University. $78 p$

10. Misbah, Feki, and Berhanu Belay. "Livelihood and Socio-Cultural Significance of Afar Goat Breed Intended For Breed Improvement Programs." Journal of Agricultural Science and Research (JASR) Vol 3 (2016): 13-22.

11. Lahoti, S.R., Chole, R.R. and Rathi, N.S. (2011)'Knowledge of indigenous technologies in livestock management' Indian J.Dairy Sci. 64(3):258-262

12. Rani, V.D. (2004) Training needs of farm women of Thrissur Taluk in dairy and poultry farming. M.V.Sc. Thesis, Kerala Agricultural University, Thrissur, $117 p$.

13. Rathod, P.K. Landge, S. Nikam, T.R. and Vajreshwari, S. (2011) 'Socio-personal profile and constraints of dairy farmers' Karnataka J. Agric. Sci., 24(4): 619-621

14. Shanmugam, M. Kumaran, S.R. Selvaraj, V. Manoharan, M. and Balasubramanyam, D. (2002) 'Knowledge level of dairy breeding practices among farmers in Chengalpattu' Indian Vet.J. 79: 814-816

15. Khurshid, N. A. B. I. L. A., and A. B. D. U. L. Saboor. "Impact assessment of economic interventions of AKRSP on the lives of rural women: A case study of northern areas of Pakistan." International Journal of Economics Commerce and Research (IJECR) 3 (2013): 49-56.

16. Shinde, S.V. (2011) 'Socio-economic profile of Dairy farmers in Solapur District of Maharashtra State' Indian Streams Res. J. $1(1): 86-100$

17. Tak, A. U. M. Chakravarty, R. Upadhyay, R. C. Meena, B. S. Rani, K. and Singh,S.A.(2011) 'Knowledge level of dairy farmers about udder health care practices and its relation to their socio-economic characteristics' Indian J.Dairy Sci.64(1):39-41

18. AREO, MARGARET OLUGBEMISOLA. "Regbe-Regbe: Multidimensional Impact of Cloth and Colour in Ojude-Oba Festival." International Journal of Humanities and Social Sciences 5.5 (2016): 55-72.

19. Vidya, P. Manivannan, C. and Sudeepkumar, N.K. (2010) 'Effectiveness of an educational interactive video-DVD on dairy health management practices in terms of knowledge gain among dairy farmers' The Online Journal of Rural Research and Policy. 5(7): 1-17. 